Khalid Ahmed Hassan AHMED1

\title{
ENHANCEMENT OF CREATIVITY AND INTELLIGENCE THROUGH LANGUAGE
}

\section{Istanbul/ Türkiye}

\section{p. 1-11}

\section{Article Information}

Article Type: Research Article

This article was checked by

iThenticate No plagiarism

detected

\section{Article History}

Received: 22/10/2020

Accepted: $03 / 11 / 2020$

published: $01 / 12 / 2020$

\begin{abstract}
:
This study aims at exploring the role of human languages in establishing solid grounds for the continuity of human creativity and intelligence. Although it is not easy to define what a language is, no one denies that language is the most essential human device that helps people to communicate and get on well with each other. This capability of communication granted language its essential role in enhancing human beings survival and transmission of human knowledge, culture and the whole material advancement and heritage. For this end the study will be a qualitative historical survey of the role of human languages in extending human bonds and relationships for the sake of survival, safety and solidarity in a wild context at the first stages of human beings presence on earth, and later in a world of advanced technology where the whole world has come to be united as if it is a small village. The study will explore some verses of the Holly Qur'an that support human creation and ability to communicate. The theoretical frame work and the related literature will be outlined and explored to support the assumption and hypotheses of this study. The importance of the study will also be stated. The study will be processed through the methodology, the procedures and the discussion that will be followed for obtaining its findings. The study will be finalized by the main obtained results and recommendations for further future studies and a summary for the whole study.
\end{abstract}

Key words: Enhancement of Creatıvity; language; Inteligence. 


\section{Introduction}

Human language is a Devine endowment by which Allah Almighty has given human beings supremacy all over the other creatures beside the faculty of mind and thinking. In a number of verses in the Holly Books it has been mentioned that Allah has created human beings in an upright better shape. Human languages, essentially, are the tools by which humanity existence and growth have been maintained and confirmed. Human languages are also the tools by which the sociological aspects of human beings have been established and strengthened. Therefore, human beings have succeeded across history to better dwell and prosper on this earth. By means of languages new inventions and discoveries are made possible for the welfare of humanity and to some kind a wise utilization of natural sources. Not only human languages do make it possible for people to explore or to find new inventions and new ways of using the available natural resources, but they also facilitate communication among nations to be aware of these discoveries and to be able to use them and to let others know and use these discovered inventions and new ways of use. Hence from the early ways of setting up fire, for instance, people are now by the advancement of science and technology can just set up fire with just pressing on a button without any difficulty and at no time. Human beings' existence on this earth is every now and then getting more facilitated as a result of the better use of the tool of human language.

The connection between language and creativity is said to be an earlier process within the linguistic growth of children as it has been mentioned in Tannen (2007) who said that children practice language creatively to establish creative processes either in different forms of arts or literature or in the creative uses of general communication or interactions in the wider social context. In other words language is the medium of acculturation to set up the features of the cultural components of the community. However, the relationship between language and culture may overlap as it has been mentioned by Lyons (1979: 433 - 34) because we may find cultural similarities between politically differently related communities. Language in fact is an essential component of the overall set up of the society or community of its speakers. Therefore, it is said that if you would like to be safe from the evils and harms of any community it would be better to learn their language. In today's world there is a great awareness about the importance of the knowledge of any community's language because this kind of knowledge is profitable and has a lot of advantages in all the aspects of humanity activities, and on the other hand the ignorance of the community's language is a loss and it has a lot of disadvantages in all the activities of that community.

For the language to be capable of responding to the needs of the community, it is always in a process of change so as to be able to meet any renewed matters or inventions and the like. According to Bynon (1979: 213) there are some linguistic and nonlinguistic factors as mechanisms for language change. The linguistic factors will be the factors that include certain linguistic aspects of change either in the lexicon, phonology, etc. The nonlinguistic factors will generally be the ones connected with personality or social traits such as age or prestigious factors to cope up with the mode of language use or style of a certain social group. The linguistic factors of change are more relevant to our present study because we need to meet the cultural advancement or material development by coining new terms to these newly invented tools or machines or ways of thinking. Bynon (1979: 217 ff.) discussed the mechanism by which the lexicon can be expanded either by 'lexical borrowing', 'Ioan translation', or 'semantic expansion'. These of course are the central processes by which new 
recurrent things can be identified. Lexical borrowing is a direct transmission of lexical items from one language into another, and languages all over the world are full of such examples of lexical borrowing. Loan translation is the process by which a concept is borrowed from another language but the structure of the lexicon is taken from the borrowing language. Semantic expansion on the other side is the process by which the semantic import or dimension of the lexicon is expanded in order to be capable of accommodating the recurrent linguistic changes of meaning and terminology. By applying these linguistic changes the language will be capable of accepting the changes and absorbing them for the welfare of the adjacent community and the cultural or material advancements that happen in the community.

\section{The Importance of the Study}

This study is Important as it focuses on an important aspect of human languages that is their reliability to be changed in order to incorporate any recurrent or renewed human advancement and development. The study is also important as it is built on the findings of previous studies in an attempt to fill in gaps within these previous studies. The study is also needed in today's world where the importance of language is extremely increasing, and the language is a central human property that enhances humanity advancement and progress. There is great humanity awareness about the importance of any single human language, and that ignoring any human language is a great social or economic loss.

\section{Methodology}

The study follows the qualitative approach and a historical survey over the related literature in its processing, discussion, findings and conclusion. For that end a review, discussion and correlation among the previous related studies will be undergone together with our own observations and experience of human languages mainly English and Arabic languages. In the first part of the discussion the theoretical frame work of the study will be outlined to include language and its importance in transmitting human knowledge and heritage. Then the need for language change in order to cope up with the renewed recurrent factors. After the theoretical framework of the study some of the previous related studies will be discussed so as to enhance the processing of this present study.

\section{Procedures}

As it has been stated within the methodology of this study that some verses from the Holly Qur'an will be explored, discussed and interpreted to show how these verses tackle the issue of human beings creation for the prime sake to worship Allah and to dwell on earth and to better use its resources and to be as representatives of Allah on this earth. Then variety of related quotes from the previous studies will be outlined, discussed and correlated with the linguistic observations related to the importance of language as a tool for enhancing human beings existence and better use of its resources to be creative and intelligent users of its resources. This kind of discussion and correlation aim at responding to the stated hypotheses in this present study mainly those connected with the human language as a tool for enhancing humans' creativity and intelligence. Human languages are by their nature and structure flexible to accept changes and new conceptions by inherent techniques within these languages nearly in all their linguistic structures and components such as semantics and syntax. 


\section{The theoretical frame work and some related studies}

Intelligence and creativity are genuine human characteristics that can be used as properties by which human beings can be distinguished from the other creatures. In a survey on human civilization in a global perspective (2010) about the importance of language it is said that 'Language,' is a unique human 'trait' that is the essence of human beings' capabilities of setting up human ideas and transmission of culture and knowledge from a period to another period. First of all we need to have definitions and classifications of what is meant by intelligence and creativity from the perspectives of the discussion and argument in this study.

According to the Wikipedia (2021) "Human intelligence is the intellectual capability of humans, which is marked by complex cognitive feats and high levels of motivation and self-awareness." Hence, and from this definition, it can be said that intelligence is involved in any human mental or cognitive activities, including, of course, the faculty of language which is a genuine innate mental or cognitive ability. On the other hand for the Wikipedia (2021) "Creativity is a phenomenon where by something somehow new and somehow valuable is formed." This newly created valuable thing may involve variety of things ranging from the intangible things such as ideas or theories to the different kinds of material or cultural inventions such as genres of literature. From these two stated definitions we can say that intelligence and creativity are closely related human properties, or we can say that intelligence may be the income of creativity and creativity is its outcome or vice versa. This is not an odd correlation between intelligence and creativity as the two are related to the human cognition. For Steinberg and Sciarini (2006: 101) who cite Malson's (1972) argument about the importance of average or better intelligence for survival in the wild. This connection between intelligence and survival is necessarily connected with the development and acquisition of a human language.

On the religious side of the picture we can say that variety of verses in the Holly Books mention something about the upright and perfect creation of human beings to be able to perform their required commitment which is worship as it has been mentioned in the Holly Qur'an in 'Sorat Al Teen (4)' " لقد خلقنا الانسن في أحسن تقويم" “Indeed We have created man in the best constitution (equipoised in the finest proportion). The interpretation of this verse is read as follows: human beings have been created in the best shape or image if compared with the other creatures. In other verses it has also been mentioned that the human being is honored by Allah as in 'Sorat Al - Isra (70) " "ولقد كرمنا بني آدم ..."And We have indeed honoured the children of Adam....." If these two verses are correlated we can say that human beings have been provided with all that enables them to be liable to worship Allah in the required order. The worship, of course is not just that is confined to the religious side, but it is as well a comprehensive wise utilization of the available earthy sources.

As it has been mentioned above that language is a genuine innate cognitive human property according to the linguistic revolution headed by the prominent American Linguist Noam Chomsky in the fifties of the twentieth century. Chomsky (2000: 120) said that the speed and accuracy by which the lexicon of the language is acquired by children is not relevant to what is found in an advanced dictionary. He justifies this by that language as an innate cognitive faculty is directly connected with human intelligence or mental faculty. For Gass and Schachter (1997: 55) there is a difference between a child acquiring his/her first language and an adult; for the child the process is cognitively innate, while for the adult it is a general process of learning in cases of adults learning of different skills and activities. This linkage between intelligence and the cognitive aspects of human language 
can be proved by the creativity by which human beings use their language to utter infinite number or utterances to express at any time novel ideas and concepts. Human language creativity is, of course, one of the fundamental values that distinguish human language from the other creatures' ways of communication.

In another study Shehu and Shittu (2015: 192) studied the importance of language in establishing successful communication for successful business projects. The language in today's world is the tool for establishing successful economic projects. Language represents the source of information that needs to be established about the project, and without access to that source of information in a form of a language and effective communication the project will never attain the aspired success. This relationship between a successful economic project and an effective communication system is of great value in today's economy because countries all over the world have come to identify this importance of communication and economy; therefore, great interest has started to be given to the teaching and learning of variety of languages in order to gain economic merits out of learning other communities languages. For Crystal (2003: 110) English language is the medium of knowledge through which all the sciences and knowledge can be transmitted to the other nations. This remark by Crystal, of course can be generalized to all the other languages if these languages reflect certain kinds of science or knowledge. The connection between the economic rewards and the knowledge of other countries' languages is of course directly connected with both creativity and intelligences in the use of human languages. The use of human languages is of course in a part a purely linguistic process, and in another it is connected with all the surrounding factors that should be taken into account for this pure linguistic mechanism to be more effective and influential. This last point has been maintained by Mesthrie et al. (2009: 4 - 5) who discussed Chomsky and Hymes' views of competence by emphasizing Hymes' persistent on using communicative competence over a mere competence to give competence its effectiveness by using the social context or surroundings for the communicative act to be influential in the appropriate social context. In other words language should be used creatively in order to attain its intended message.

In studies on language and culture Wierzbicka (1999: 7) discussed the overlap that may happen between a language and another language mainly in expressions related to feelings and emotions, for an example she compared between Russian and English by mentioning a word that is not found in English with a similar equivalent term; in such a case the term will be given a literal translation that may not give the exact intended meaning. Therefore, the absence of an equivalent lexical item will affect the import or the sense of the meaning. Lexicons in languages are generally studied as either diverged or converged entities of language. They converged when they have more or less the same semantic import, and they diverged when they don't have more or less similar semantic values.

Gabora and Russon (2011) have explored the issue of human intelligence and language through their enquiry about the reasons for which human intelligence has evolved across history. First they outlined that human beings transmit their innovations through effective communal behavior through which human heritage, inventions, culture, etc. can be transformed from place to place and from time to time. Then they listed some of the factors that help human intelligence evolve across history; these factors on one hand are biological mainly in terms of what they call sexual or group selection, through which the individual may select the appropriate individual through who the sexual reproduction may help in reproducing new individuals with the required genetic qualities. On the other hand intelligence evolves through the cultural transmission of innovations and the cultural heritage through joint communications by means of language. This survey addresses directly our present study, and the role of intelligence and creativity through the medium of language. 
In her study of socio - economic development in Malawi Mkwinda-Nyasulu (2013) agrees that language and its prime function communication are essential components in development in general. Then she shifts the discussion to finding a unifying form of language or a kind of a lingua franca that makes communication more efficient in order to achieve the set up goals and aspirations of the development of the community. This unifying language should not ignore the presence of other minor languages. In another study Arcand and Grin (2013) studied the relationship between language and economic development; they emphasized the importance of a common shared language in the community whatever the language is; such types of languages facilitate transactions among people who share more or less the same sets of languages and they also reduce problems of contractions between landlords and their peasants. This emphasized role of language can be generalized to include any human activity through which the community seeks to attain the requested objectives and aspirations. Therefore, language can be said to be the most influential tool by which the community can put in practice any set up objective or aspiration in any required field. The identification of a unifying language should not distract the community from acknowledging other languages because the knowledge of other languages is needed for more open - minded cooperation with the broader worldwide communities for more better chances and a better understanding of what others achieve, and the knowledge of such languages will lead to more open opportunities around the world, or in other words the community will not be put in a close circuit away of what goes on in this wider universe. Therefore, within the scope of sociolinguistics we often come across language planning strategies and techniques by which a direct intervention will be done on the functions of language in order to promote or demote them. Wardhaugh (2006: 357) for example said something about 'corpus planning' as 'standardizing a language or one of its varieties' in order to be capable of serving any possible community need. By this process this language or its variety will be supplied by all the linguistic or codification processes to make it liable to respond to the required language functions such as new lexicons, dictionaries, literature, etc.

In a pure linguistic study Ghonchepour and Moghaddam (2018) have studied the relationship between intelligence and the learning of English language in general and certain skills such as grammar and reading comprehension in particular. The most important outcome of this study is that there is a high positive correlation between intelligence and the learning of these English language skills. In other words, intelligence enhances performance and success in the learning of English language and of course of other languages as well. The results of this study can also be generalized in all the other activities.

\section{Discussion, Results, Conclusion and Recommendations}

Through the discussion in this section the prime aim is to obtain the findings of this present study. For this end we need to base the discussion on a correlation between the religious aspects of intelligence, creativity and human language depending mainly on the verses from the Holly Qur'an that mention these human traits on one side, and on the other the related studies which have been discussed in this study. The findings of the study will be the frame work on which the recommendations and the suggestions for future studies based. 
The Holly Qur'an verses will tackle in particular concepts related to the creation of human beings, how they are uniquely endowed with a means of communication, their prime aim on this earth to worship Allah, and how human beings are asked to behold and conceptualize their surroundings as central features of intelligence and creativity.

First it is better to mention briefly the verses which mention something about human beings creation and how they are endowed with language in order to be representatives of Allah on earth. There are also several verses in the Holly Qur'an that activate and urge human beings to behold and conceptualize their surroundings to strengthen their faith on Allah and to be true worshipers and believers. For the ease of discussion and processing we are going to divide the set of selected Holly Qur'an verses into three domains; in the first we start with the verses that mention something about the creation of human beings as representatives of Allah on earth; then we move on to the verses that tackle the issue of endowing people with the needed requirements to best dwell on earth for the sake of worshiping Allah; and in the last list we mention the verses in which mediation and conceptualization as entities of creativity and intelligence have been mentioned. After discussing and interpreting the verses we set up the needed correlation between the reviewed literature and the three lists of verses.

بسم الله الرحمن الرحيم واذ قال ربك للملائكة اني جاعل في الأرض خليفة قالو اتجعل فيها من يفسد فيها ويسفك الدماء ونحن نسبح بحمدك ونقدس لك قال اني أعلم ما لا تعلمون (30) (البقرة)

And (recall) when your Lord said to the angels: 'I am about to place My vicegerent on the earth.' They submitted: 'Will You put Your (vicegerent) on the earth such as will do mischief in it and shed blood, whilst we are engaged in glorifying You with celebrating whilst we are engaged in glorifying You with celebrating our Praise and extolling Your Holiness (all the time)?' (Allah) said: 'I know that which you do not know.'

و اذ قال ربك للملائكة اني خالق بشرا من صلصال من حما مسنون (28) (الحجر) And (recall) when your Lord said to the angels: 'I am about to create a human organism from old (and) black stinking mud.

فاذا سويته ونفخت فيه من روحي فقعوا له سجدين (29) (الحجر)

So when I accomplish the perfection of his (physical) constitution into his real being, and My (divine) spirit into (the inner self of) this (human physical) organism, then fall down prostrate before him.'

This first list of verses and the verses which are mentioned above within the introduction of this present study indicate clearly that the creation of human beings is a specialized kind of creation to the extent that Allah Almighty has blown the Divine spirit on the human beings. The angels have also been requested to fall down in front of the human being to show the honor that is given to him over all the other creatures. In addition to these verses there are also other verses in the Holly Qur'an that their interpretations indicate clearly that human beings have been endowed with language in order to complete the picture of the perfect up right creation of the human beings on one hand and to better worship Allah in the right order. Worship is not only a matter of a religious commitment or religious performance but it is a comprehensive human activity that involves all the vital human activities to behave and utilize the earthy sources in wise and ideal ways. In the coming list of verses we are going to mention the verses that requested human beings to behold and conceptualize all the Divine signs in the universe for more wise and perfect engagement on worship the thing that could easily be correlated with intelligence and creativity. 
ولقد مكنكم في الأرض الرجيم وجعلنا لكم فيها معايش قليلا ما تشكرون (10) (الأعراف)

And surely, We established you firmly on earth with control and authority and created therein means of sustenance for you. Yet you thank but little.

$$
\text { بديع السمُؤت والأرض واذا قضى امرا فانما يقول له كن فيكون (112) (البقرة) }
$$

$\mathrm{He}$ is the One Who has originated the heavens and the earth, and when He wills to (originate) a thing, He only says to it: 'Be,' and it becomes.

This second list of verses indicates clearly that human beings have been endowed with all the means, either physical, mentally, or emotionally to well dwell and utilize the available sources on earth. Then originality, intelligence and creativity have been mentioned as original divine traits to which people should submit, and as well should be themselves reflectors of these divine traits as representatives of Allah on earth. Therefore, people have been requested in a number of verses to better behold, watch and conceptualize their surroundings to be intelligent and creative for a better utilization of these earthy sources on one hand and on the other to better worship their creator (Allah) to fulfill the requested demand of being as vicegerents of Allah on earth, and to be committed to their worshiping of Allah in its wider perspective, as a complete living cycle, as well. Hence the list of verses below will tackle the aspects of conceptualization and its great connection with both intelligence and creativity as the central concepts of this present study.

$$
\begin{aligned}
& \text { بسم الله الرحمن الرحيم } \\
& \text { او لم ينظروا في ملكوت السمُؤت و الأرض و الروان ما خلق الله من شئ و ان عسى ان يكون قد اقترب اجلهم فباي حديث بعده } \\
& \text { يؤمنون (185) (الأعراف) }
\end{aligned}
$$

Have they not looked into the kingdom of the heavens and the earth and whatever Allah has created (apart from that? And have they not considered that) it may well be that their appointed term (death) has drawn near? Then what will they believe in after this?

قل سيروا في الأرض فانظروا كيف بدأ الخلق ثم الله ينشئ النشأة الاخرة ان الله على كل شئ قدير (20) (العنكبوت)

Say: 'Travel in the land (to study life in the universe), then observe (i.e., mediate and research) as to how He initiated (the life of) Creation and how He raises and nourishes the second life (passing it through evolutionary stages). Surely, Allah has perfect power over all things.

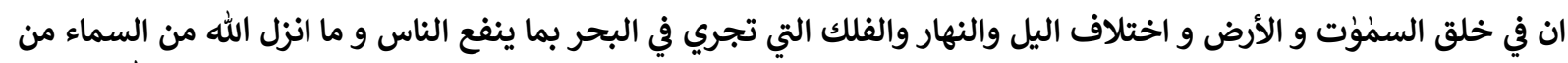

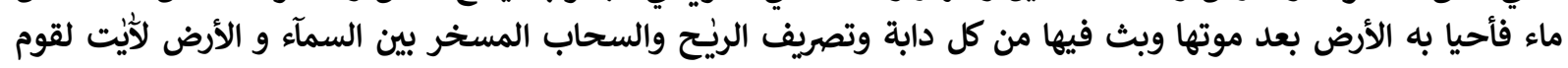
يعقلون (164) (البقرة)

Verily, in the creation of the heavens and the earth, and in the alteration of the night and the day, and in the ships (and vessels) which sail through the ocean carrying cargo profitable for the people, and in the (rain) water which Allah pours down from the sky, reviving therewith the earth to the life after its death, and (the earth) in which he has scattered animals of all kinds, and in the changing wind directions, and in the clouds (that trail) between the sky and the earth, duty - bound (under Allah's command) - certainly (in these) are (many) signs (of Allah's Power) for those who put their reason to work. 
و من آيته أن خلق لكم من انفسكم ازواجا لتسكنوا اليها و جعل بينكم مودة و رحمة ان في ذلك لآيت لقوم يتفكرون (21)

And (also) of His signs is that He created for you mates of your own kind so that you acquire peace from them, and He created between you love and mercy. Verily, in this (system of creation) there are signs for those who mediate.

In the third list of verses there is a divine request for people to either mediate or to apply a process of conceptualization or reasoning on the signs of nature and creation that strengthen faith. Mediation or reasoning is directly connected with cognition and the mental capacities, and these, of course, will finally be connected with the faculty of language as (also) a cognitive property. Mediation is said to be the kind of thinking that is run by those whose faith is firm and greater than those who apply conceptualization; therefore, they only need very limited evidences to strengthen and confirm their faith in Allah, for that end we feel that the verses are not extended or detailed in the case of mediation. However, the verses in general could be taken as further sources of evidence to indicate that all the human beings' senses are addressed to behold the universe for more faith on one hand, and on the other to benefit from all these available resources.

After discussing the above lists of verses, we need to apply a further correlation between the verses and the literature reviewed in this study in order to set up the findings of this study. As a first point in this correlation, we can say that there is a great evidence that intelligence, creativity, human languages are mental cognitive entities which are correlated, and they should go hand in hand with each other. In other words no intelligence or creativity without the presence of a language as an intermediate entity that makes it possible for people to do any human activity whether it is mental, emotional or social. Second, the human language is a central component of the creation of the human being that makes this kind of creation a special kind of creation that gives human beings privileges over all the other creatures. Third, the human language is the medium through which some kind of compromise can be made to activate or put into practice all the mental or emotional processes including of course intelligence and creativity; to the extent that we can say no intelligence or creativity without language.

\section{Conclusion}

In conclusion, and in the light of the points discussed above we can list the following findings:

There is a strong evidence that:

1. Language is a facilitator and initiator of human intelligence.

2. Creativity is enhanced and processed by language.

3. Intelligence is enhanced and developed by language

4. Language, intelligence, creativity are interrelated cognitive human faculties for better living conditions.

5. Human languages are cognitive entities and media of mediation and conceptualization.

This present qualitative historical surveyed study starts with an introduction to set the scene for the discussion to be developed to attain the above obtained findings in the light of the theoretical background and the reviewed literature which are further supported by the exploration of some related Holly Qur'an verses. The importance, the methodology and the procedure of the study have also been explained to make it easy for the study to be processed scientifically according to the set up plan. After the discussion and the correlation of the reviewed literature and the related verses of the Holly Qur'an the findings of the study have been enlisted. In order to sum up this study logically 
according to the techniques of research we need to set up the following recommendations and suggestions for further future studies so as to let this study be replicated in future research projects. We feel that the following list of recommendations will help to further this study in similar future studies:

1. More intensive correlation between some related literature and the related Holly Quran are needed for future studies.

2. A comparative study between the Holly Qur'an and the other Holly Books is needed to study intelligence and creativity in a linguistic perspective.

3. Enhancement and creativity through a wider social aggregation and social solidarity.

4. The importance of language in dealing with the renewed universal problems.

5. The role of multilingualism and bilingualism in processing and enhancing human intelligence and creativity.

\section{Sources}

The Holly Qur'an

The Glorious Qur'an

Altabarie Interpretation of the Holly Qur'an

Ibin Kathier Interpretation of the Holly Qur'an

\section{Bibliography}

Arcand, Jean - Louis and Grin, Francois (2013) Language in economic development:

Is English special and is linguistic fragmentation bad? https://www.researchgate.net/publication/265185653

Bynon, Theodora (1979) Historical Linguistics. Cambridge Textbooks in Linguistics.

Chomsky, Noam (2000) New Horizons in the Study of Language and Mind. Cambridge University Press.

CRAIMC01_001-039hr.qxp 8/12/10. The Birth of Civilization. Global Perspective

Crystal, David. (2003). English as A Global Language. Cambridge University Press.

Gabora, L., \& Russon, A. (2011). The evolution of human intelligence. In R. Sternberg \& S. Kaufman

(Eds.), The Cambridge handbook of intelligence (pp. 328-350). doi:10.1017/CBO9780511977244.018

Gass, Susan M. and Schachter, Jacquelyn (1997) Linguistic Perspectives on Second Language Acquisition. Cambridge University Press.

Ghonchepour, Mousa and Moghaddam, Mahdiye Pakzad (2018). The Role of Intelligence in Learning English as a Foreign Language. Research in English Language Pedagogy. Relp (2018) 6(1): 25-38

Lyons, John (1979) Introduction to Theoretical Linguistics. Cambridge University Press.

Mesthrie,Rajend, Joan Swann, Ana Deumert and William L. Leap, (2009) Introducing Sociolingistics. Edinburgh University Press.

Mkwinda-Nyasulu, Betty (2013) Role of language in socio - economic development: the semiotics are right. J. Humanities. (Zomba), 23, 2013/2014. 
Shehu, Halima and Shittu, K.O. (2015) The Bridge to Economic Prosperity: The Role of English Language Communication in Entrepreneurship. International Journal of Humanities and Social Science Vol. 5, No. 7; July 2015

Steinberg Danny D. and Sciarini, Natalia V. (2006) An Introduction to Psycholinguistics. Pearson Longman

Tannen, D. (2007) Talking Voices: repetition, dialogue and imagery in conversational discourse. Cambridge: Cambridge University Press.

Wardhaugh, Ronald (2006) An Introduction to Sociolinguistics. Blackwell Publishing.

Wierzbicka, Anna (1999) Emotions Across Languages and Cultures: Diversity and Universals. Cambridge University Press.

Wikipedia (2021) Human Intelligence. https://en.m.wikiped 